\title{
Learners' Views Regarding the Use of Social Networking Sites in Distance Learning
}

\section{Abstract}

In this study, it was aimed to examine the use of learning management systems supported by social networking sites in distance education and to determine the views of learners regarding these platforms. The study group of this study, which uses a qualitative research approach, consists of 15 undergraduate students who resumed their education in Turkey. The data were gathered via a semi-structured interview form which consists of open-ended questions. Content analysis was used in the analysis of the data. According to the results of the study, it has been revealed within the scope of the course that the students have positive attitudes towards the use of social networking sites and distance education applications and these applications have positively affected the quality of communication between instructors and students. Furthermore, it was seen that the students made comments relating to the interesting aspects of the applications and the difference between distance education and face-to-face learning.

Keywords: Social networking sites; distance learning; learning management systems; Blackboard; CourseSites; Ning 


\section{Introduction}

Distance education has existed for more than a hundred years. Distance education, which emerged with the idea of education at home without being dependent on time and place, has existed in many forms for years from learning via letters to videos, from radio and TV lessons to internet applications as technology has improved (Gürgan, 2012). Because of this, many different tools and methods have been used for realizing distance education activities (Smith, 2009). Within the scope of life-long learning, today, web technologies are actively used in distance education applications which aim to bring people in different places together. These technologies help people to learn by themselves synchronously or asynchronously and provide opportunities for creating an interactive environment via audio-visual elements. Student-student interaction is seen as one of the key points in providing student satisfaction in distance education (Zhao et al., 2005; Tallent-Runnels et al., 2006). In addition, it has been stated that interaction in learning increases success and engenders a positive attitude, an increase in motivation, and consequently more meaningful and permanent learning (Kim et al., 2007). The negative effects of earlier distance education applications and the use of internet technologies that do not meet needs in terms of learner-learner and learnerinstructor interaction have decreased. The use of learning management systems (LMSs), such as Blackboard, Moodle and WebCT, which were often used in higher education institutions in the 1990s, has not only facilitated the distribution and sharing of education material and information, but also increased the level of interaction among learners, institutions, and instructors. Tools such as instant messaging systems, discussion boards, chat rooms, and blogs have given learners the opportunity to interact not only with instructors but also with other learners (Grisham \& Wolsey, 2006). However, recently it has been seen that these overly structured (Brady, Holcomb, \& Smith, 2010) tools used in LMSs make some students reluctant to use these platforms (Aghili et al., 2014; Divall \& Kirwin, 2012; Meishar-Tal, Kurtz, \& Pieterse, 2012; Schroeder \& Greenbowe, 2009) as they provide less student communication, satisfaction and motivation when compared to the face-to-face classroom environment from the perspective of students (Aghili et al., 2014; Thoms \& Erylmaz, 2014; MeisharTal, Kurtz, \& Pieterse, 2012; Rozac et al., 2012; Duncan \& Young, 2009; Young, 2007). LMSs are also tending to be instructor centric and instructors primarily use these platforms for information sharing (Mott, 2010). In these official environments, learners are limited to merely interacting with others. Furthermore, LMSs are considered to decrease motivation and enthusiasm and fail to support personalization (DeSchryver et al., 2009).

For this reason, the researchers have suggested that the aforementioned platforms get support from other technologies in order to resolve these problems and provide social experience (Brady, Holcomb, \& Smith, 2010; Lee \& McLoughlin, 2010). Within this scope, social networking sites (SNSs) have caught attention due to their encouragement of communication (Rozac et al., 2012), student engagement (Aghili et al., 2014), motivation, personal interaction and collaboration (Veletsianos, Kimmons, \& French, 
2013; Veletsianos \& Navarrete, 2012; Greenhow, Robelia, \& Hughes, 2009). It was considered that SNSs can be used to overcome the limitations of LMS (Aghili et al., 2014; Tess, 2013; Veletsianos, Kimmons, \& French, 2013; Veletsianos \& Navarrete, 2012; Wang, 2011).

SNSs are defined as web sites which provide opportunities for users to increase levels of communication by connecting with one another and to share personal content, features which are the basic characteristics of online communities (Buss \& Strauss, 2009). According to J unco and Mastrodicasa (2007), SNSs are "an easier way to connect in a disconnected world." Wheeler, Yeomans, and Wheeler (2008) state that SNSs provide unique opportunities for students to share their ideas, showcase their creativity, and get rapid feedback from their friends. SNSs which are designed to form virtual groups via the sharing of experience and personal information and connecting with friends are increasing day by day in today's world. Although there are many SNSs such as Bebo, LunarStorm, Mixi, and Orkut, the most popular ones are Facebook, MySpace and Twitter. These sites have increasingly become an essential communication tool for people (Brady, Holcomb, \& Smith, 2010). Individuals with common interests can connect by sharing information in the form of photos, videos, links, and notes; and they can collaborate by using discussion environments (McCann, 2009). In particular, SNSs help people who have problems with initiating and maintaining formal or informal social relationships as they decrease communicative barriers and encourage people to make interactions, as is the case with some other types of computer-supported communication (Ellison, Steinfeld, \& Lampe, 2007). Many researchers support the use of SNSs in increasing student engagement and forming communities in higher education classes (Aghili et al., 2014; Hoffman, 2009). According to a report prepared by New Media Consortium and ELI (2007), not only do SNSs attract people, they also attract their attention, foster their participation, and lead users to revisit past experiences, all of which are seen as desirable qualities in educational materials. SNSs give learners an opportunity to create personal profiles which help them take ownership of their learning space (Meishar-Tal, Kurtz, \& Pieterse, 2012). SNSs are also useful tools for creating a sense of presence, supporting student participation, and building online communities (Lee \& McLoughlin, 2010; Naveh et al., 2010). Furthermore, it was stated that SNSs can improve learners' high order thinking skills depending on the tasks instructors choose (Callaghan \& Bower, 2012; Lu \& Churchill, 2012). For all of these reasons, the use of SNSs is significantly beneficial, especially in higher education contexts. But some researchers have suggested not using SNSs due to their disadvantages for learners and instructors such as feeling less safe with personal data and exposing distractions in the learning environment (Petrovic et al., 2014; MeisharTal, Kurtz, \& Pieterse, 2012).

To summarise, the use of LMSs as primary education tools, especially in higher education institutions, is rapidly increasing (Petrovic et al., 2014; Brady, Holcomb, \& Smith, 2010). According to a study by Allen and Seaman (2008), the rate of high school and university students registering in at least one such class is increasing day by day. At 
the same time, the popularity of SNSs such as Facebook, Friendster, LinkedIn, LiveJ ournal, and MySpace is continuously increasing and it has expanded to a wide user base (Boyd \& Ellison, 2007). When the popularity of LMSs and SNSs and the educational benefits of SNSs are considered, some educators suggest merging these two platforms to improve the quality of learning (Petrovic et al., 2014; Thoms \& Eryılmaz, 2014; Razali et al., 2013; Iahad, 2012; Rozac et al., 2012; Brady, Holcomb, \& Smith, 2010; Feuer, 2009). In this context, it was aimed to investigate students' views about the use of LMSs supported by SNSs in distance education in this study.

\section{Method}

\section{The Model of the Study}

This study, which uses a qualitative research approach, has been designed as action research. Action research provides in-depth information to the researcher about the process and results of the application. In addition, it is more often used as part of a qualitative research approach because generalization is not the primary purpose and qualitative research has a more flexible structure than quantitative research (Yıldırım \& Şimsek, 2008). From this standpoint, it has been attempted to determine what learners think about the application process and to record the results of social networking site supported distance education courses which were carried out in the course of the study.

\section{Study Group}

The population of the group consists of Frrat University students. Criterion-based sampling was selected from the purposeful sampling methods in determining the study group. In criterion-based sampling, the study group is formed by selecting the ones that meet the formerly determined criteria. A ready-made criterion list can also be used in addition to one prepared by the researcher (Patton, 2002). For this purpose, the criteria were formulated by the researcher. In the study, the participants were chosen from 25 students who participated both in social network and distance education applications within the scope of the experimental study, which was carried out in relation to the support of distance education systems with SNSs, during the 2011-2012 spring term at Firat University. In selecting the study group, active participation in distance education and social network applications, high-level expression skills, and the desire to participate voluntarily were taken to be the criteria. First of all, 16 students who had actively participated in distance education and social network applications and who had demonstrated high-level expression skills during the process of the applications were chosen, then they were asked whether or not they were willing to volunteer for the interview stage. Interviews were conducted with 15 students who said that they were willing to volunteer for the study. 


\section{Data Collection}

Data were collected with the interview form developed by the researcher, with which the views of the learners were related to the application process of the research. The interview was prepared in accordance with the semi-structured interview type and an individual interview was carried out. The interviews were carried out following the completion of the application process. The questions in the interview form were related to certain topics such as the differences between the applications from the perspectives of the learners, positive and negative aspects of the applications, their effects on communication, interesting aspects, hardships in usage, their wish to use them in professional life and for them to be used in the other courses. For this purpose, an interview form was developed in the first stage. The studies related to the topic in the literature were examined and 18 open-ended questions were written in accordance with the principles to be paid attention to in preparing the interview form. After that, in a collaborative study between two experts and the researcher, the questions were reviewed and, as a result, a form was prepared consisting of 10 questions. All interviews were conducted in the Firat University Faculty of Education. During the interviews, a flexible method was followed in asking the questions in accordance with the structure of the semi-structured interview, and when seen as necessary, more in-depth information was acquired by asking more questions. At the same time, the questions were asked in a conversational manner and after stating that the subjects' names would be kept secret, an attempt was made to create a warmer and more intimate environment, and, therefore, the students were more comfortable. The researcher was the interviewer in all interviews. The researcher placed importance on encouraging the participants to give detailed information and give feedback to the responses he/ she gave in order to provide an efficient interview during the interview process. In the study, all interviews were recorded. A word processor program was used for enabling later analysis of the recordings and written copies of them were prepared. In addition, the interviews were recorded without modifying any of the students' views.

In the study, CourseSites, which is the free software provided by Blackboard, was used in carrying out the distance education applications; and Ning, a social networking site, was used in carrying out the social network applications. Ning helps to simulate a class environment by designating an area which is exclusive to certain courses to which only members can have access thus increasing the participation of the students in internal and external activities.

\section{Data Analysis}

Within the scope of the study, the qualitative data attained were analyzed in accordance with content analysis principles. Content analysis is defined as the process of reaching a set of concepts and relationships within which the data can be analyzed. Providing a deeper analysis, it is used in revealing the concepts and themes that could not be formed as a result of descriptive analysis. With content analysis, data which are similar are gathered under certain concepts and themes and these data are interpreted by arranging 
them in a way that the reader can understand. For this purpose, the data are firstly conceptualized, then the occurring concepts are arranged in a systematic way and, finally, the themes explaining the data are formed and the process is completed (Strauss \& Corbin, 1990).

Within the scope of data analysis, the first step of the transmission of recordings attained from the interviews to the digital environment was conducted via a word processor program. Then, for the purpose of conducting a valid and reliable analysis, it was decided that the process should be conducted in a computer-supported way. Qualitative data analysis software was used which provides opportunities for visual outputs to be created as a result of the analysis. In the analyses conducted, the written source, which was transmitted to the electronic environment, was first read carefully. Then, the coding process was initiated and free code lists were formed. After a detailed examination of the free code lists, the codings were systematically grouped and categorized. The qualitative data analysis process was complete once the themes had been formed.

Results

\section{Differences between the Distance Education Process and the Face-to-Face Education Process}

The views of learners related to the differences between the distance education and the face-to-face learning activities were examined under two themes: course environment and physical environment (Figure 1).

The students put the most emphasis on the process of listening to the course related to the differences between the distance education activities and the face-to-face learning activities. When the loads were examined more carefully, not having items that distract attention was the topic which was most talked about, and the rest follow in sequence: providing more chances to express oneself more carefully, distraction of excessive use of chat rooms, providing active participation, saving more time, providing chances for getting immediate feedback, provision of the opportunity to repeat, the course may not be listened to, the control of the process of listening to the course belongs to the students, interacting with foreigners makes people worried. The topic with the second greatest degree of emphasis was the physical environment. The remaining sub-themes have been ranked in sequence in descending order of degree of emphasis: it is not dependent on the place, the worry of not being face-to-face, the screen provides visual easiness, distraction by people who have nothing to do with the course. Below are some samples from the views of students which are the sources for these sub-themes. 
In face-to-face education, the door is opened and I get distracted, my friends talk to each other and I get distracted, certainly there is always something to distract me. However, I have noticed that in my room, I focus only on the computer. (Student L)

I have the ability to talk when a friend sits near me in traditional environments and I talk to him/her. However, there was not anything like this in virtual classroom. I have listened to the course directly because there was nobody near me to talk to. (Student D)

Because there is a seating order in traditional education, sometimes we have had problems in seeing the slides, students or the teacher, but we can see the board directly in the virtual classroom. (Student A)

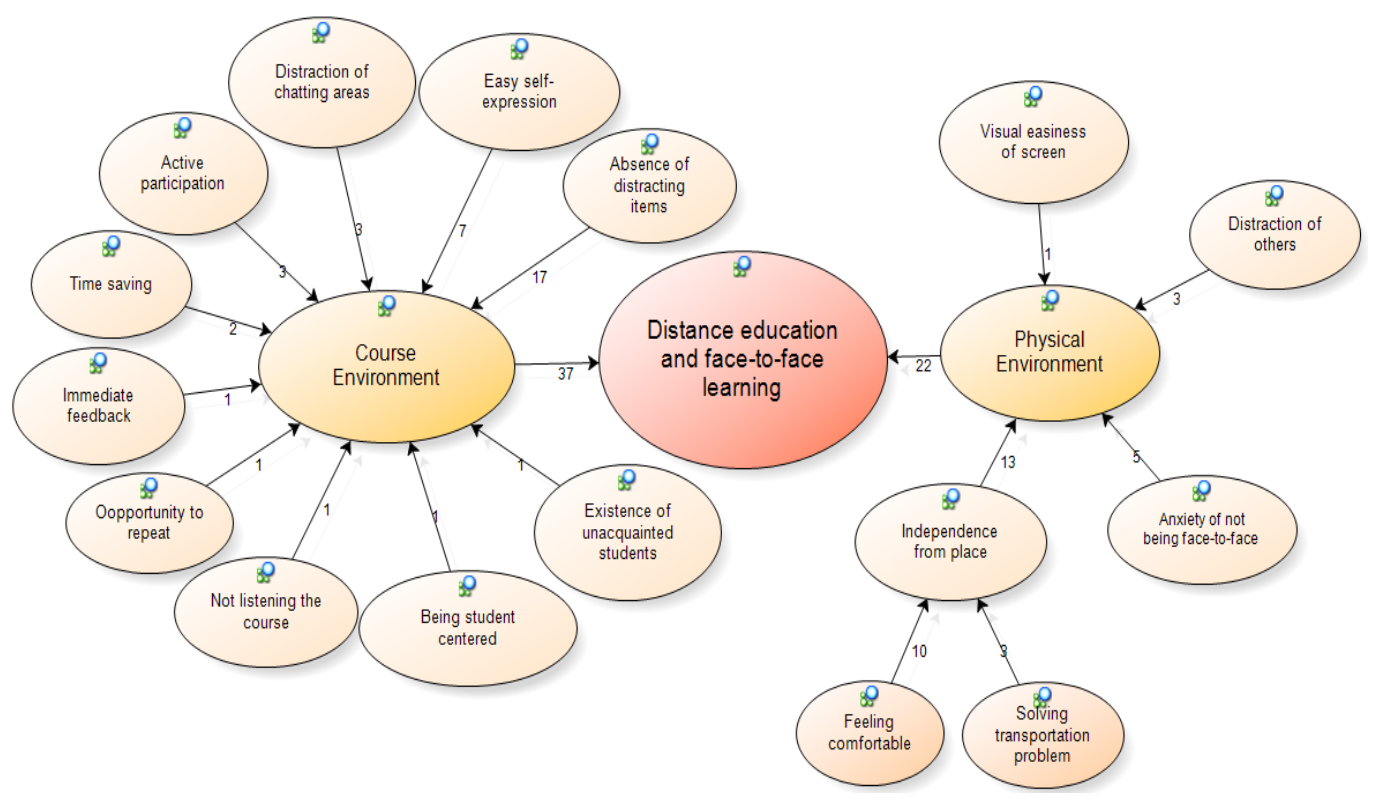

Figure 1. The differences between the distance education process and the face-to-face education process.

\section{Participation in Activities in the Social Networking Site}

Students stated that there was a high degree of participation in the social networking site and distance education platform. Information relating to the participation of the students in social networking activities has been gathered under four sub-themes: the 
contribution of the sharings, increasing communication, giving chances to get to know these kinds of environments, and solutions to communication problems (Figure 2).

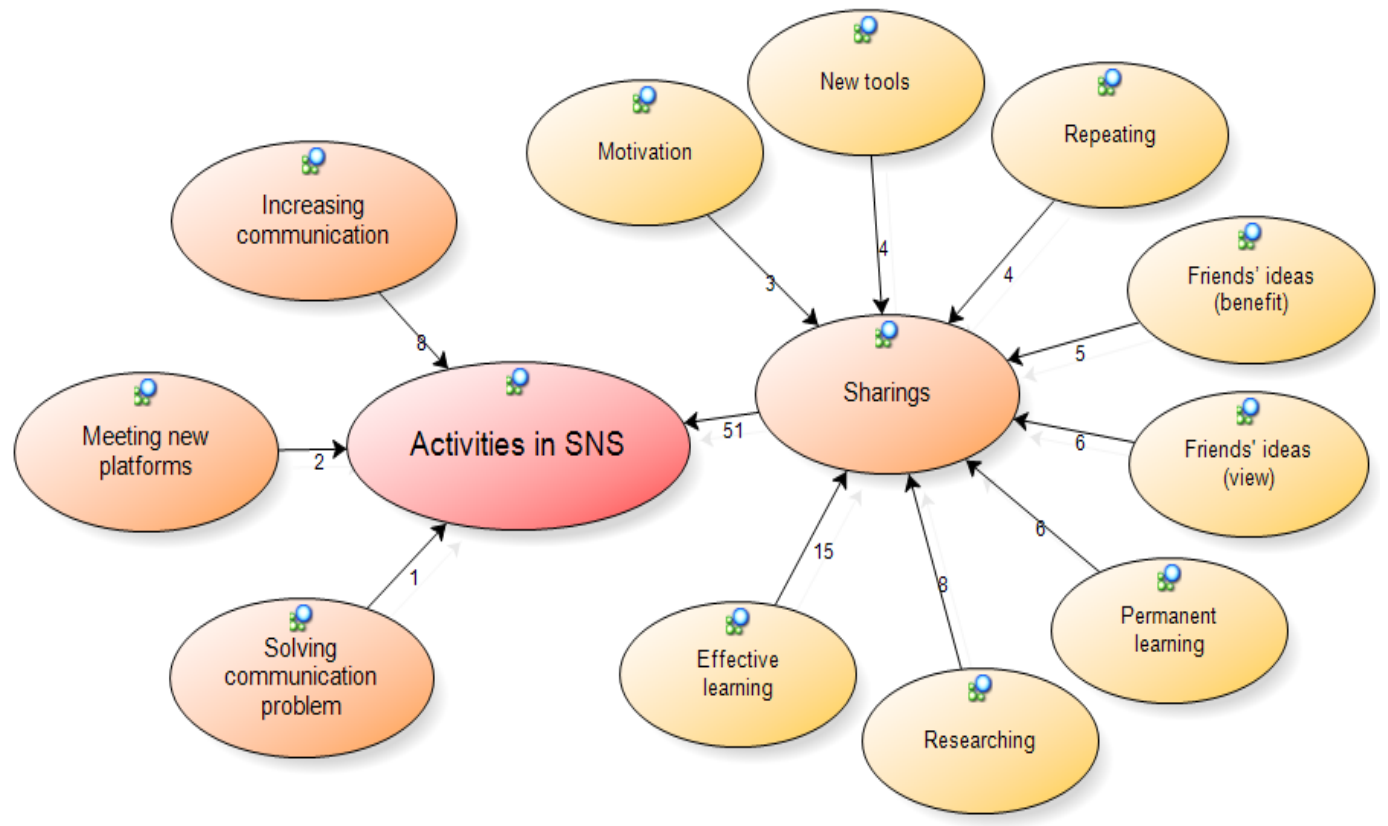

Figure 2. The model related to the participation in activities in the social networking site.

In particular, the students' level of participation in sharing caught our attention in the participation coding of activities carried out within the scope of applications conducted in the social networking process. With regard to the interviews, it was seen that there were eight different sub-categories arising from the detailing of the loads belonging to the themes. These sub-categories were sequenced in the following order: provision of efficient learning, nudging students towards research, provision of permanent learning, viewing friends' ideas, benefitting from friends' ideas, provision of the opportunity to repeat, the use of tools which cannot be provided in the face-to-face classroom environment, and increase in motivation.

We can learn in a broader way when we read and analyze both our answers and the answers of our friends. (Student F)

It encouraged me to research further, because actually there was a matter of comparison. I saw what my friends had written, and it forced me to think like Can I write a better one? Can I share more efficiently? (Student $\mathrm{H}$ )

It makes a person glad also in terms of himself/ herself to be sharing new things about the course together with the 
instructors and our friends... The instructor's feedback to the sharing of information motivates us. (Student E)

\section{Positive and Negative Aspects of Distance Education Courses}

When the views of students related to the themes are examined in detail, it is noteworthy that the students put more emphasis on the positive aspects of distance education courses. In addition, while the sub-theme on which the most positive emphasis was put is independence of time and place, the sub-theme on which the most negative emphasis was put is distraction of excessive use of chatting areas (Figure 3).

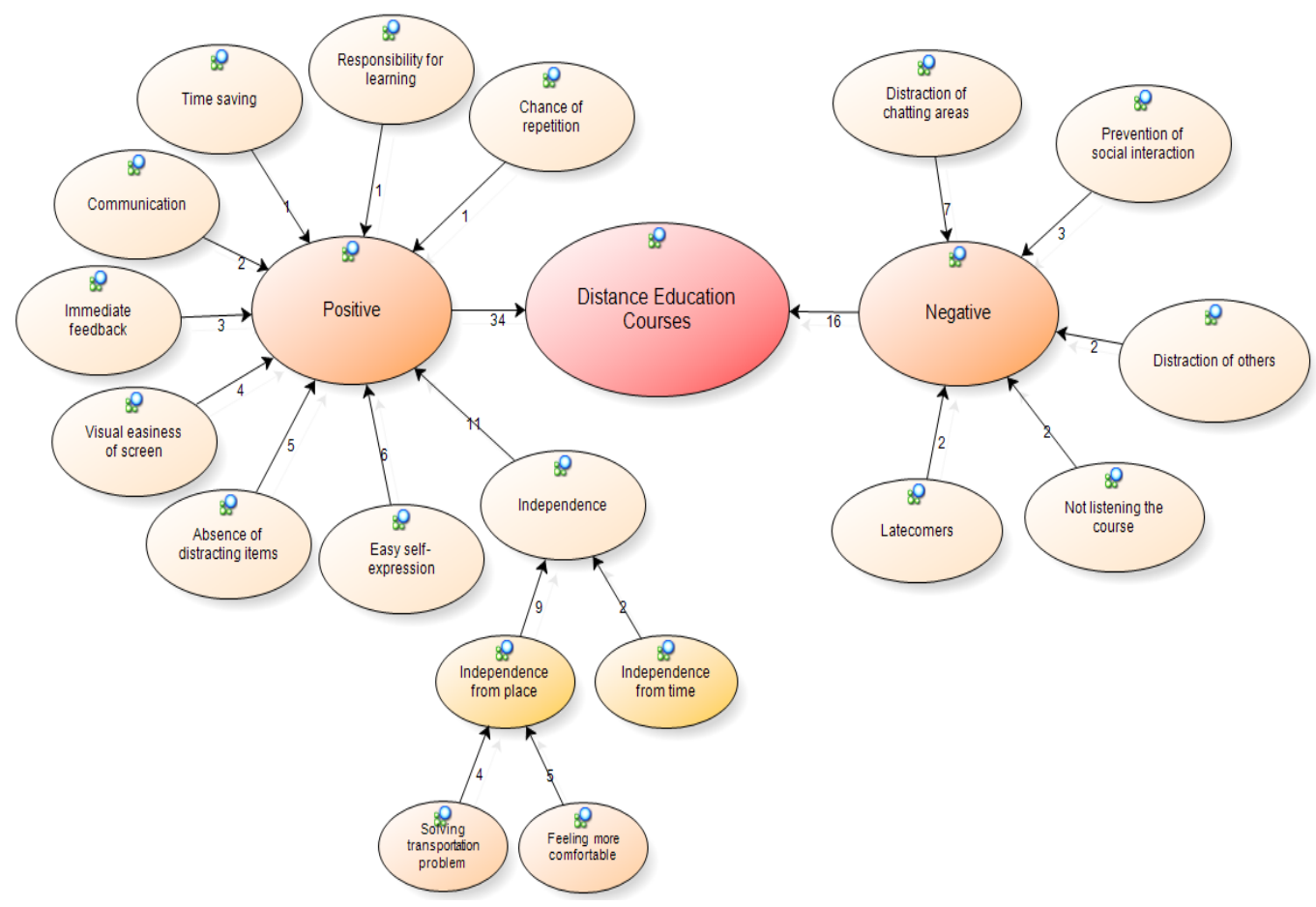

Figure 3. The model related to the positive and negative aspects of lecturing in the distance education platform.

When the views of students were examined, it was determined that the theme with the most positive views has eight sub-categories. These subthemes have been sequenced in descending order as follows: independence of time and place, provision of easy selfexpression, not having items that distract attention, visual easiness of the screen, provision of immediate feedback, increasing the level of communication, saving time, and provision of the opportunity to repeat. It can be seen that independence of time and place, the theme which has the most positive emphasis, has been separated into two sub-themes, independence of time and independence of place; and the independence of place sub-theme has been further separated into two sub-themes, feeling more comfortable and solution to transportation problems. The most negative aspect of 
distance education applications was stated to be the distraction of excessive use of chatting areas by the students during the course. And distraction by people who have nothing to do with the course, the course may not be listened to, and waiting for latecomers follow this theme.

The courses could be in our homes because there was not any problem of going to school and coming back from the school... We had the opportunity to listen to the course any time, wherever we are. (Student O)

I am a person who gets distracted in face-to-face education, but I did not get distracted so much in there. I was totally focused on the lesson and understood it better. (Student L)

It destroys the social interaction... it prevents the continuity of communication. However, there is a chatting area, but again, the reciprocal interaction; I think that reciprocal communication is better. (Student $\mathrm{K}$ )

There can be different people in the environment because you are in the environment you want to be in. Because I live in the dormitory, my friends were entering the room and I got distracted by them. (Student A)

Off-topic messaging affected me negatively. (Student L)

\section{Negative Aspects of Using the Social Networking Site}

The majority of the students said there is no negative aspect to the benefits they receive from using a social network in the education process. It was also seen that the other students talked about some negative aspects. These negatives have been gathered under themes such as sharings, reluctance of students in attending to the environment, and not being able to delete messages in the chatting area. 


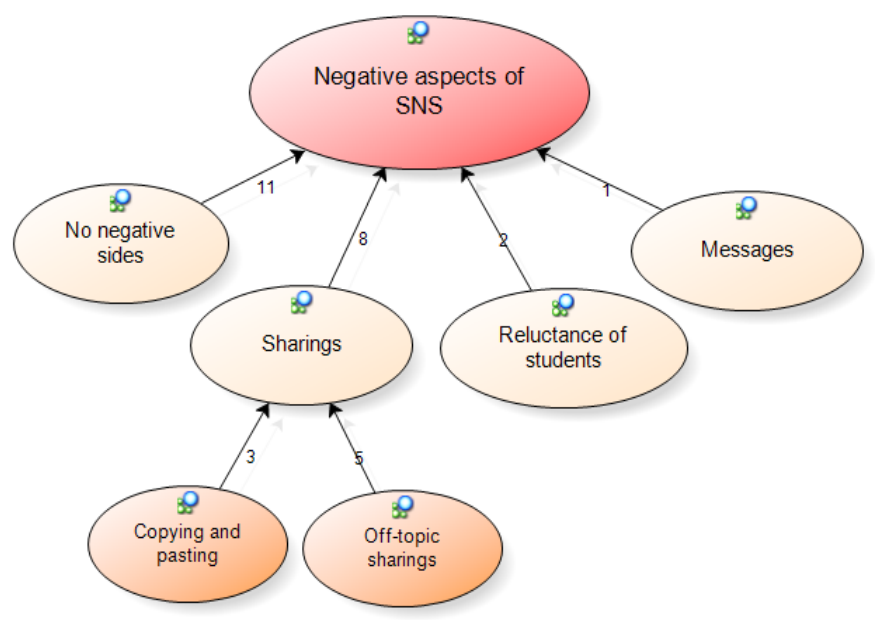

Figure 4. Model related to the negative aspects of using the social networking site.

With regard to the interviews conducted with the students, it is seen in Figure 4 that the theme sharings is separated into the two sub-themes, sharings which are not related to the topic and using copy and paste.

I cannot see the negative aspects of it so much. It is positive in general. (Student J)

I think there are no negative aspects, because I have always seen the positive aspects of it. (Student D)

Some of us have also shared things which were not related. (Student L)

\section{Communication in the Application Platforms}

The majority of the students stated that the activities carried out both in distance education and through the social network affected their relationships positively both with their friends and the instructors. However, it is also noticeable that the application either did not have any effect on the relationships between some students or negatively affected some relationships. The model related to communication in the application platforms is presented in Figure 5. 


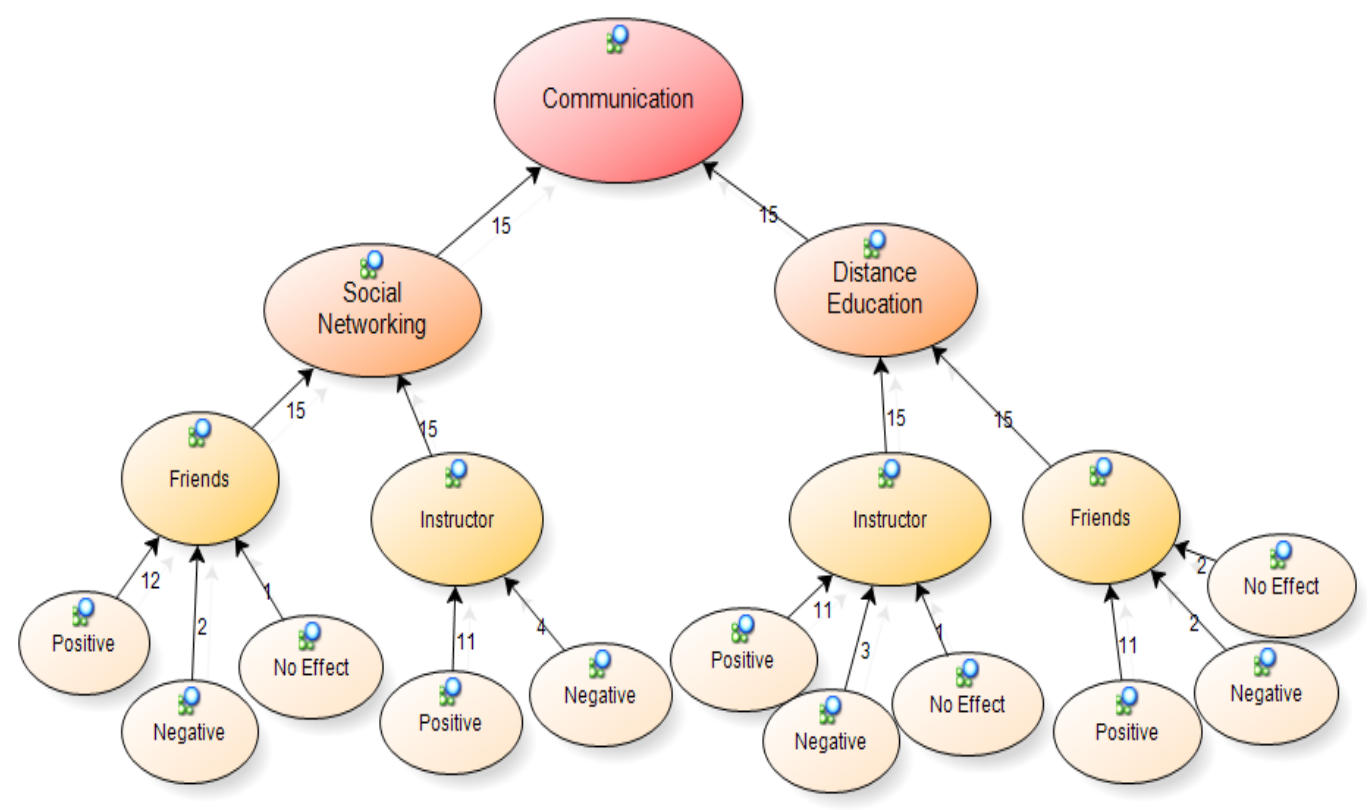

Figure 5. Model related to communication in the application platforms.

I think it has a positive effect. I believe that we have better quality communication with the instructor in the virtual classroom. (Student J)

We had a greater level of interaction with our friends. We had the opportunity to communicate with everybody due to the chat rooms. (Student A)

It has increased... we spent more time there, we talked about some things and shared information, and now we are closer... Our discussion in there has been reflected in our work after classes and we got on well. It has been better. (Student L)

It negatively affects us. It is impossible to capture the environment of a real classroom via the virtual classroom. (Student K)

People you don't know, you become irritated by some of their behaviors. Because you have to be with them in that environment, you have to tolerate them and their activities actually. (Student I) 


\section{Interesting Aspects of the Platforms}

The responses given related to the interesting aspects of the platforms were separated into the two sub-themes, distance education and social network. The interesting aspects of the distance education platform are ordered as follows from most emphasized to least emphasized: providing communication as much as it can be done in face-to-face class, the completion of all activities that can be conducted as a whole class, attendance from wherever students want, gathering everyone in one place who participate from different places, presenting a different environment, having the properties like chatting, white board, sound and camera, the control of listening to the course belongs to the students, the visual ease of the slides in the screen, availability via just an Internet connection and an extension and not having a formal environment as it is in the traditional classes. For the social network platform, it is sequenced as sharings, indication of the existence of a social network for educational purposes, provision of efficient communication, availability for using anytime, and being more beneficial than expected. The model formed in relation to this theme is provided in Figure 6.

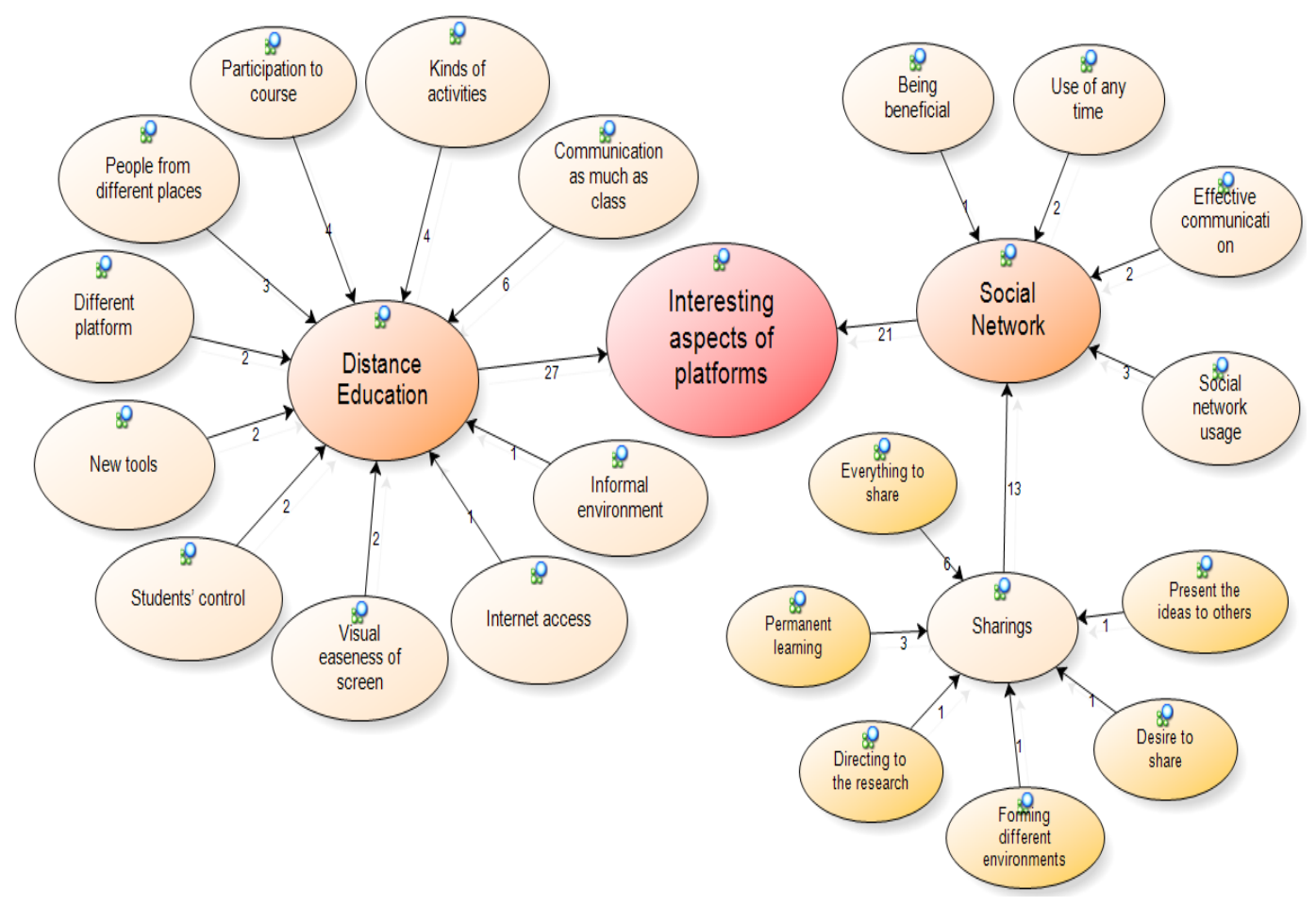

Figure 6. Model related to the interesting aspects of the platforms.

The sharings sub-theme which has the largest information load related to the social network platforms consists of six sub-themes in total: sharing anything wanted, provision of permanent learning, nudging students towards research, forming different 
discussion environments, desire of sharing, and provision of the opportunity to share ideas with friends.

What caught my attention was seeing the instructor in front of us. I felt as if it was face-to-face. (Student $\mathrm{H}$ )

We can do anything we do in class there. We can participate in the courses. (Student J)

We were commenting freely...We were writing the suggestions we wanted to make. (Student $\mathrm{N}$ )

All our friends could access the questions and ideas we shared in the forums. And everybody could answer my question. (Student $\mathrm{H}$ )

\section{Discussion}

In this study which was conducted on the effects of the learning management systems on learners' views, an attempt was made to suggest the primary differences between the distance education and the face-to-face learning process. It has been seen that the differences between each educational process depend on listening to the course and physical environment as two main topics. Students have explained that they cannot concentrate exclusively on the course because they want to chat with their friends in the face-to-face learning environment. However, they expressed that there is no such situation in virtual classroom activities conducted within distance education and they concentrate on the course because there are no distracting objects in the environment (Petrovic et al., 2014). Another important result in this issue is that the students both feel more relaxed and express themselves more easily in these environments. This result matches with the related reviews within the literature which concern the issues of students being more relaxed and expressing themselves more easily (Holcomb, Brady, \& Smith, 2010). Examples of differences between the applications are being independent of location, being anxious due to not being face-to-face, the interface providing visual ease of use, and distraction of other students with whom students are not acquainted. The course environments being independent from location negates transportation problems and allows the student to relax in his/ her environment.

Within the scope of the study, emphasis has been put on contributions in sharing, improving communication, providing an opportunity to meet such environments, and removing the communication problems concerning contributions of activities made in the social networking site. The students have indicated that the most important contribution in the activities made in this platform is sharing. Accordingly, in the literature, the students have indicated that they consider Ning, a SNS used in the present study, as providing ease in sharing ideas and engaging in discussion (Hoffman, 
2009; Holcomb, Brady, \& Smith, 2010). Moreover, it has been stated that the most important advantage of Ning is its allowance for individuals to upload videos, images, and files (Brady, Holcomb, \& Smith, 2010). In addition, there are some results suggesting that the SNSs to be used must contain properties such as students being a member, the ability to create a profile page, share information, and to establish academic and social user groups (Gürgan, 2012). Detailed investigations in the present study have shown that students describe the benefits of sharing as its provision of effective and permanent learning experiences, the ability to view the opinions of their friends, the ability to utilize the opinions of their friends, its tendency to direct them to research resources, the fact that it allows them to repeat, its provision of tools which cannot be accessed in a face-to-face educational environment, and its tendency to improve their level of motivation. In the studies within the literature, it has been concluded that SNSs used for educational aims have improved communication (Smith, 2009). In addition, it has been stated that using SNSs in learning and teaching activities provides several advantages and the most important ones are student participation, motivation, personal interaction, and personal learning (Iahad, 2012; Meishar-Tal, Kurtz, \& Pieterse, 2012; Veletsianos \& Navarrete, 2012; Hoffman, 2009). Similarly, Mazer, Murphy, and Simonds (2007) state that SNSs affect the class environment positively and improve levels of motivation. In a study related to viewing the opinions of friends and utilizing their comments, it has been underlined that SNSs allow users to both see the opinions of friends on a certain issue and to utilize these opinions. In the same study, it was indicated that SNSs allow for thinking in order to view and answer friends' comments (Holcomb, Brady, \& Smith, 2010). In addition, in the literature, it has been specified that sharing in a SNS is beneficial in relation to seeing the opinions of all members of a group. In the present study, students have stated that improvement in communication is another advantage of SNSs. Correspondingly, it has been stated in the literature that SNSs allow for better communication between students when distance education and face-to-face education are compared (Brady, Holcomb, \& Smith, 2010).

The result of investigating the positive and negative aspects of LMS is that the students concentrate mostly on positive aspects. On the topic of independency from time and place, the aspect of independence of location especially comes to the forefront. This situation allows students to express themselves easily in the platform and negates transportation problems. However, as distinct from the present study, in the literature, there are studies in which students have indicated that they prefer the face-to-face learning environment in spite of the aforementioned positive aspects of SNSs (Brady, Holcomb, \& Smith, 2010). Within the course, the students have indicated that the most negative aspect of using the virtual classroom, which is a technology of distance education, is the overuse of the chat area. It has been confirmed that this situation makes the students distracted in the course. Moreover, according to the results of the present study, attention has been drawn to the fact that some students think that distance education prevents socialization in spite of the opinions of other students. It has been seen that the same results have been reached from the studies within the literature; it gives less satisfaction to the student than face-to-face learning due to 
distance education's prevention of face-to-face social interaction (Hoffman, 2009; Young, 2007); debate platforms used in LMSs make the students unwilling to participate and affects the quality of social interaction negatively (Schroeder \& Greenbowe, 2009).

Another issue emphasized in the study is the determination of the negative aspects of using SNSs within the course. During interviews, most of the students stated that there are no negative aspects to it. Accordingly, in the literature, it has been stated that there are no negative aspects to usage of the Ning platform (Brady, Holcomb, \& Smith, 2010). It can be said that using SNSs in educational activities creates a high level of motivation in the students. In addition, it has been emphasized that SNSs which allow expansion of the borders of the class can be used to educational ends (Karabulut, 2009). Negations in the process of social networking activities are not wishing to participate within the environment and not being able to delete text entered in the chat area. In this issue, interactions unrelated with the topic and the copying and pasting of another person's opinions have been considered as negations. Accordingly, J ohannesen and Eide (2000) emphasize that students show respect towards others' opinions and they must not copy and paste information which they do not have in their studies. As distinct from the results of the present study, it has been suggested that SNSs such as Ning have a number of advantages but also some disadvantages and it has been stated that one of the most important disadvantages is time lost in students' replying to other interactions in the environment (Holcomb, Brady, \& Smith, 2010).

The study has shown at what level distance education and social networking platforms affect student-student and student-instructor communication. Each platform affects the communication of students both with each other and with instructors positively. When it is considered that student-student interaction is the key point from the perspective of student satisfaction in distance education, it can be seen that it carries a great deal of importance (Thoms, 2014; Veletsianos \& Navarrete, 2012; Meishar-Tal, Kurtz, \& Pieterse, 2012; Tallent-Runnels et al., 2006; Zhao et al., 2005; Aijan \& Hartshorne, 2008). In the present study, it was noteworthy that students who are shy in terms of establishing communication with the instructor in face-to-face learning environments have stated that they better cope with their shyness on the platform in question. Correspondingly, it has been stated that the introduction of SNSs in educational areas improves student-instructor communication, cooperation, interaction, and the quality of the e-education process (Meishar-Tal, Kurtz, \& Pieterse, 2012; Despotovic-Zrakic, 2011). In the literature, it has been suggested that these environments provide communicative opportunity to individuals who cannot establish communication in faceto-face environments (Holcomb, Brady, \& Smith; 2010); SNSs used for educational purposes can be an effective technological tool in order to develop online communication among students who take distance education courses in higher education (Brady, Holcomb, \& Smith, 2010). Similarly, it has been emphasized that not only do online social network tools remove communicative barriers, they actively encourage communication (Bargh, McKenna, \& Fitzsimons, 2002; Ellison, Steinfeld, \& 
Lampe, 2007). Moreover, it has been underlined that LMSs and SNSs must be used together in order to improve communication and interaction (McCarty, 2010).

In this process, the attractive aspects of the LMS and SNS whose activities were made have been evaluated. This situation can be considered as an indicator of the fact that students can establish communication in the LMS to the same degree that they can in the classroom environment and they can perform all activities which can be performed in the classroom environment in the LMS. It has been seen that the students find sharing to be most attractive. Benson (2009) stated that SNSs support information sharing by providing the participants opportunities to search, form common interest points, and partake in collaborative activities in distance education. Another important issue which has attracted the attention of the students on SNSs is the presence of a SNS which can be used for education and can be accessed only by the members. The studies made on this issue show that Facebook and Web 2.0 technologies are not always successful tools in learning and teaching activities; there is a difference between students' preferences when using these technologies for daily interaction with their family and friends and their preferences when using these technologies in formal education environments (Hoffman, 2009; Waycott et al., 2010; McCarthy, 2010). The students see using Facebook and other SNSs which they often use in their life for educational purposes can represent interference in their private lives (Aghili et al., 2014; Veletsianos \& Navarrete, 2012; McCarthy, 2010; Hoffman, 2009; Schroeder \& Greenbowe, 2009). In addition, these activities must be under the control of an administrator or an instructor in education environments due to confidentiality and security problems (Anderson, 2005). This is why it can be said that closed SNSs like Ning being used in education has developed dramatically.

When the results of the study are evaluated, it can be said that SNSs are supportive platforms to LMSs. Similarly, in the literature, it has been stated that supporting LMSs, especially those used in higher education, with SNSs is beneficial to effectively facilitate learning (Petrovic et al., 2014; Thoms \& Eryllmaz, 2014; Razali et al., 2013; Iahad, 2012; Rozac et al., 2012; Gürgan, 2012; Despotovic-Zrakic, 2011; Brady, Holcomb, \& Smith, 2010; Holcomb, Brady, \& Smith, 2010; Anderson, 2005; Karabulut, 2009; Smith, 2009; Noesgaard, 2008). It should be noted that combining these two platforms provides more student engagement, personal interaction, communication, peer-to-peer feedback, and social experience in distance education. In this study, Ning was used as a social network platform. Ning is a social network platform which only members who are invited by the instructor can access. In future studies, other SNSs which are used for educational purposes can be investigated. Further research can also examine how to evaluate meaningful learning tasks to promote student engagement and collaboration in distance learning activities. 


\section{References}

Allen, I. E., \& Seaman, J . (2008). Staying the course: Online education in the United States. Needham, Mass: Sloan Consortium.

Aghili, M., Palaniappan, A. K., Kamali, K., Aghabozorgi, S., \& Sardareh, A. S. (2014). Unifying informal and formal learning environments: Educational use of social network sites through implementing community of inquiry framework. International J ournal of e-Education, e-Business, e-Management and eLearning, 4(3), 191-196.

Anderson, T. (2005). Distance learning-social software's killer AP? Conference of the Open and Distance Learning Association ofAustralia (ODLAA). Adelaide, South Australia: University of South Australia.

Benson, V. (2009). Embedding web 2.0 strategies in learning and teaching. In Lytras, Miltiadis D., Damiani, Ernesto, Ordóñez de Pablos, Patricia (Eds.), Web 2.0: The business model (pp. 237-248). Springer US.

Boyd, D. M., \&Ellison, N. B. (2007). Social network sites: Definition, history, and scholarship. J ournal of Computer-Mediated Communication, 13(1), 210-230.

Brady, K. P., Holcomb, L. B., \& Smith, B. V. (2010). The use of alternative social networking sites in higher educational settings: A case study of the e-learning benefits of ning in education. J ournal of Interactive Online Learning, 9(2), 151- 170.

Buss, A., \& Strauss, N. (2009). Online communities handbook: Building your business and brand on the web. USA: New Riders Press.

Despotovic-Zrakic, M. S. (2011). Fostering engineering e-learning courses with social network services. 19th Telecommunications Forum TELFOR 2011.22-125, 2224 November 2011, Serbia, Belgrade.

DeSchryver, M., Mishra, P., Koehler, M., \&Francis, A. P. (2009). Moodle vs. Facebook: Does using Facebook for discussions in an online course enhance perceived social presence and student interaction? The Society for Information Technology and Teacher Education International Conference 2009 (pp. 329336).

DiVall, M. V., \& Kirwin, J .L. (2012). Using Facebook to facilitate course-related discussion between students and faculty members. American J ournal of Pharmaceutical Education, 76(2).

Duncan, H. E. \&Young, S. (2009).Online pedagogy and practice: Challenges and strategies. The Researcher, 22(1), 17-32. 
Ellison, N. B., Steinfield, C., \& Lampe, C. (2007). The benefits of facebookfriends: Social capital and college students' use of online social network sites. J ournal of Computer-Mediated Communication, 12(4), 1143-1168.

Feuer, G. (2009). Net generation students and their use of social software: Assessing impacts on information literacy skills and learning at a laptop university.University of Toronto, Department of Theory and Policy Studies Ontario Institute for Studies in Education, Toronto.

Greenhow, C. G., Robelia, B., \& Hughes, J . (2009). Learning, teaching, and scholarship in a digital age Web 2.0 and classroom research: What path should we take now? Educational Researcher, 38(4), 246- 259.

Grisham, D. L., \&Wolsey, T. D. (2006). Recentering the middle school classroom as a vibrant learning community: Students, literacy, and technology intersect. J ournal of Adolescent \&Adult Literacy, 49(8), 648-660.

Gürgan, S. (2012). Açık ve uzaktan öğrenmede etkileşim aracı olarak web 2.o teknolojilerinin kullanımı: kurumsal bir sosyal ă̆ sitesinin özelliklerinin belirlenmesi. Anadolu Üniversitesi, Sosyal Bilimler Enstitüsü, Eskişehir.

Hoffman, E. S. (2009). Evaluating social networking tools for distance learning. Proceedings of Technology, Colleges, and Community Worldwide Online Conference, 2009(1), 92-100.

Holcomb, L., Brady, K., \& Smith, B. (2010). Ning in education: Can non-commercial, education-based social networking sites really address the privacy and safety concerns of educators? In D. Gibson \& B. Dodge (Eds.), Proceedings of Society for Information Technology \&Teacher Education International Conference 2010 (pp. 528-531).

Iahad, N. A., Mirabolghasemi, M., \&Huspi, S. H. (2012). A blended community of inquiry approach: The usage of social network as a support for course management system. International Conference on Computer \& Information Science.

J ohannesen, T., \& Eide, E. M. (2000). The role of the teacher in the age of technology: Will the role change with use ofinformation and communication technology in education? European J ournal of Open and Distance Learning.

J unco, R., \& Mastrodicasa, J . (2007). Connecting to the net.generation. Washington, D.C.: National Association of Student Personnel Administrators. 
Karabulut, A., Braet, D., Lindstrom, D., \& Niederhauser, D. S. (2009). Student level of commitment and engagement with ning as a learning management system. In C. Maddux (Ed.) Research highlights in information technology and teacher education 2009 in (pp.125-133). Chesapeake, VA: Society for Information Technology and Teacher Education (SITE).

Kim, D., Grant, E., Huang, C., \& Seo, J . H. (2007). Future design of Korean ubiquitous classrooms. Retrieved from http:// www.keris.or.kr/ upload/board01/112903413.pdf on 12.09.2012

Lee, M. J . W., \& McLoughlin, C. (2010). Beyond distance and time constraints: Applying social networking tools and Web 2.0 approaches to distance learning. In G. Veletsianos (Ed.), Emerging technologies in distance education (pp. 61- 87). Edmonton, AB: Athabasca University Press.

Lu, J ., \& Churchill, D. (2012). The effect of social interaction on learning engagement in a social networking environment. Interactive Learning Environments, 1, 1-17.

Mazer, J . P., Murphy, R. E., \& Simonds, C. J . (2007). I'll see you on Facebook: The effects of computer-mediated teacher self-disclosure on student motivation, affective learning, and classroom climate. Communication Education, 56(1), 117.

Meishar-Tal, H., Kurtz, G., \&Pieterse, E. (2012). Facebook groups as LMS: A case study. The International Review of Research in Open and Distance Learning, 13(4), 33-48.

McCann, K. H. (2009). Virtual communities for educators: An overview of supports and best practices. Technology, Colleges, and Community Conference 2009 Proceedings (pp. 137-142).University of Hawai, Manoa,

McCarthy, J . (2010). Blended learning environments: Using social networking sites to enhance the first year experience. Australasian J ournal of Educational Technology, 26(6), 729-740.

Mott, J . (2010). Envisioning the post-LMS era: The Open Learning Network. Educause Quarterly, 33, 1-9.

Naveh, G., Tubin, D., \& Pliskin, N. (2010). Student LMS use and satisfaction in academic institutions: The organizational perspective. The Internet and Higher Education, 13(3), 127- 133.

New Media Consortium, \& EDUCAUSE Learning Initiative (ELI). (2007). The Horizon Report.The New Media Consortium. Retrieved from http:// www.webcitation.org/ 5iJ WOjmBq on 09.08.2012 
Noesgaard, K. (2008). Bridging eLearning and social networks.University of Victoria, Department of Computer Science, Canada.

Patton, M. Q. (2002). Qualitative research and evaluation methods. Thousand Oaks, CA: Sage.

Petrovic, N., J eremic, V., Cirovic, M., Radojicic, Z. \& Milenkovic, N. (2014). Facebook versus Moodle in practice. The American J ournal of Distance Education, 28,117- 125 .

Razali, S. N., Shahbodin, F., Bakar, N., Hussin, H., Ahmad, M. H., \& Sulaiman, N. (2013). Incorporating learning management system with social network sites to support online collaborative learning: Preliminary analysis. Advances in Visual Informatics, 8237, 549-557.

Rožac, J ., Buendía, F., Ballester, J ., Kos, A., \& Pogačnik, M. (2012). Integration of learning management systems with social networking platforms. In eLmL 2012, The Fourth International Conference on Mobile, Hybrid, and On-line Learning (pp. 100-105).

Schroeder, J ., \& Greenbowe, T. J . (2009). The chemistry of facebook: Using social networking to create an online community for the organic chemistry laboratory. J ournal of Online Education, 5(4).

Smith, B. V. (2009). Use of online educational social networking in a school environment. North Carolina State University, Raleigh, North Carolina.

Strauss, A. L., \& Corbin, J . (1990). Basics of qualilative research: Grounded theory procedures and techniques. Newbury Park, CA: Sage.

Tallent-Runnels, M. K., Thomas, J . A., Lan, W. Y., Cooper, S., Ahern, T. C., Shaw, S. M., $\&$ Liu, X. (2006). Teaching courses online: A review of the research. Review of Educational Research, 76(1), 93-135.

Tess, P. A. (2013). The role of social media in higher education classes (real and virtual) - A literature review. Computers in Human Behavior, 29(2013), 60-68.

Thoms, B, \& Erylmaz, E. (2014). How media choice affects learner interactions in distance learning classes. Computers \& Education, 75(2014), 112-126.

Veletsianos, G., Kimmons, R., \&French, K. D. (2013). Instructor experiences with a social networking site in a higher education setting: Expectations, frustrations, appropriation, and compartmentalization. Educational Technology Research and Development, 61(2), 255-278. 
Veletsianos, G. \& Navarrete, C. (2012). Online social networks as formal learning environments: Learner experiences and activities. The International Review of Research in Open and Distance Learning, 13(1), 144-166.

Wang, Q., Woo, H. L., Quek, C. L., Yang, Y. \& Liu, M. (2011). Using the Facebook group as a learning management system: An exploratory study. British J ournal of Educational Technology, 43(3), 428-438.

Waycott, J ., Bennett, S., Kennedy, G., Dalgarno, B., \& Gray, K. (2010). Digital divides? Student and staff perceptions of information and communication technologies. Computers \& Education, 54(4), 1202-1211.

Wheeler, S., Yeomans, P., \&Wheeler, D. (2008). The good, the bad and the wiki: Evaluating student-generated content for collaborative learning. British J ournal for Educational Technology, 39(6), 987-995.

Yıldırım, A., \& Şimşek, H. (2008). Sosyal bilimlerde nitel araştırma yöntemleri. Ankara: Seçkin Yayıncılık.

Young, S. (2007). On-campus and distance teaching: how do student ratings differ andwhat does that mean for improving instruction? American Educational Research Association Annual Meeting, 10 October.

Zhao, Y., Lei, J ., Yan, B., Lai, C., \&Tan, H. S. (2005). What makes the difference? A practical analysis of research on the effectiveness of distance education. TeachersCollege Record, 107(8), 1836-1884.

\section{Athabasca University $\mathbf{a}$}

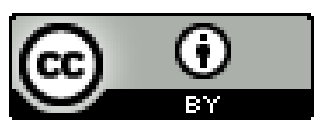

